UDC 612.2:(546.48+546.81):612.014.4

https://doi.org/10.26641/2307-0404.2019.1.162310

\title{
V.I. Fedorenko \\ THE SUBSTANTIATION OF THE MAXIMUM \\ DAILY PERMISSIBLE DOSES OF LEAD \\ AND CADMIUM IN EVERYDAY DIET
}

Danylo Halytsky Lviv National Medical University

Pekarska Str. 52, Lviv, 79010, Ukraine

e-mail:lnmu.fedorenkov.i@gmail.com

Львівський національний медичний університет ім. Данила Галицького

вул. Пекарська, 69, Львів, 79010, Украӥна

\author{
Цитування: Медичні перспективи. 2019. Т. 24, № 1. С. 73-80 \\ Cited: Medicni perspektivi. 2019;24(1):73-80
}

Key words: cadmium, lead, acute, subacute and chronic experiments, maximum daily permissible dose, maximal noneffective dose

Ключові слова: свинець, кадмій, гострі, підгострі, хронічні досліди, допустима добова доза, максимальна неефективна доза

Ключевые слова: свинеи, кадмий, острые, подострые, хронические опыты, допустимая суточная доза, максимальная неэффективная доза

\begin{abstract}
The substantiation of the maximum daily permissible doses of lead and cadmium in everyday diet. Fedorenko V.I. The article is dedicated to the bright memory of Prof. Shtabsky B.M. (the 90 ${ }^{\text {th }}$ anniversary) and comprises a fragment of results of experimental investigations conducted under his supervision in 1984-1989 years. They are related to the methodological approaches to the conducting acute, subacute, and chronic experiments, as well as analysis of the results and verification of the maximum daily permissible dose (MDPD) of lead and cadmium in the everyday diet. In the acute experiments it has been established that lead nitrate belongs to the group of the low-toxic compounds, Cadmium nitrate belongs to the mid-toxic compounds, while both are considered to be highly cumulative. The toxicity and the level of cumulation does not depend on the carrier - water, milk, vegetable oil. In subacute and chronic experiments the comparative toxicity of Ionic (comes with water and nourishment) and biocommunicated (liver and kidney homogenate, cottage cheese) forms of metals in the range of doses 1/10-1/100000 LD so $_{\text {and }}$ additionally $1 / 500000 \mathrm{LD}_{50}$ for cadmium has been studied. Toxicometrically significant distinctions under the action of the aforementioned forms have not been detected. The excretion of $\delta$-aminolevulinic acid and coproporphyrin with urine, and concentration of SH-groups in the blood plasma and liver tissue and protein in urine under the effect of cadmium in the effect of lead appeared to be the most demonstrative. Both metals possess clear gonadotoxical effect, they cause genetic effects, which can be determined by cytogenetic method, and in the Ames test with presence of liver S-9 microsomal fraction. Maximal non-effective supra-background dose $D E^{0}{ }_{50} 0,0015 \mathrm{mg} / \mathrm{kg}$ for lead, and 0,00005 $\mathrm{mg} / \mathrm{kg}$ for cadmium have been established on the basis of analysis of "dose-effect" dependency in subacute and chronic experiments, having taken into consideration results obtained according to the method of loading by same metals. Taking into the account natural metallic background dose with daily diet $(0,0025 \mathrm{mg} / \mathrm{kg}$ for lead, $0,0005 \mathrm{mg} / \mathrm{kg}$ for cadmium of of the body weight), the DPD of lead and cadmium in everyday diet is recommended at the level of $0,004 \mathrm{mg} / \mathrm{kg}$ and $0,00055 \mathrm{mg} / \mathrm{kg}$ of the weight of the body respectively.
\end{abstract}

Реферат. Обоснование допустимых суточных доз свинца и кадмия в суточных рационах питания. Федоренко В.И. Статья посвящена светлой памяти проф. Б.М. Штабского (к 90-летию со дня рождения) и содержит фрагмент результатов экспериментальных исследований, проведенных под его руководством в 1984-1989 г2., касающихся методических подходов к постановке острых, подострых и хронических опытов, анализа результатов и обоснования допустимих суточных доз (ДСД) свинца и кадмия в суточном рациионе питания. В острых опытах установлено, что нитрат свинца относится к группе малотоксичных соединений, нитрат кадмия - к среднетоксичным, оба сильнокумулятивные. Токсичность и степень кумуляции не зависит от носителя - воды, молока, растительного масла. В подострых и хронических опьтах изучена сравнительная токсичность ионных (при поступленнии с водой и кормом) и биосвязанных (гомогенат печени, почки, молочнокисльй творог) форм металлов в диапазоне доз 1/10-1/100000 ЛД кадмия. Токсикометрически значимые различия в действии указанных форм не обнаружены. Наиболее показательньми оказались при действии свинца экскрещия $\delta$-аминолевулиновой кислоть и копропорфирина с мочой, кадмия - концентрация SH-груп в сыроватке крови и ткани печени, и белка с мочой. Обоим металлам свойственно выраженное гонадотоксическое действие, они вызывают генетические эффекты, обнаруживаемые циттогенетическим методом и в тесте Эймса в присутсивии микросомальной фракиии S-9 печени. 
На основе анализа зависимостей ”доза-эффект” в подострых и хронических опытах с учетом результатов, полученных методом нагрузок одноименными металлами, установлены максимальные неэффективные надфоновые дозы ДЕ ${ }_{50}$ для свиниа - 0,0015мг/кг, для кадмия - 0,00005 мг/кг. С учетом естественной металлической фоновой дозы с суточным рачионом питания (для свинца - 0,0025 мг/кг, кадмия 0,0005 мг/кг массы тела) ДСД свинца и кадмия при поступлении с пищей рекомендуется соответственно на уровнях 0,004 мг/кг и 0,00055 мг/кг массы тела.

Dedicated to the light memory of Prof. Borys Mykhailovych Shtabsky (to the 90th anniversary of his birth)

In June 2019, Doctor of Medical Sciences, Professor Borys Mykhailovych Shtabsky - a wellknown scientist-hygienist and toxicologist, academic, Yu.S.Kagan's prizewinner of the Ukrainian Scientific Society of Toxicologists would have celebrated his 90th birthday. His name is associated with many fundamental and applied research papers, officially recognized teaching and methodological manuals and practical recommendations for scientists, doctor-hygienists and toxicologists, particularly those related to the study of toxicity and danger of harmful chemicals, original concept of cumulation, new criteria and methods for estimating cumulation of xenobiotics, their hygienic regulation in water of reservoirs, air, food products, as well as chemical safety of children and adults. Head of the Department of Hygiene and Prophylactic Toxicology (1981-2000), Prof. B.M. Shtabsky developed a new line of research on nutritional toxicology and chemical safety of man, studied the actual concentration of lead and cadmium in foodstuffs of the Western Ukraine, worked methodical approaches to hygienic regulation of heavy metals in foods. Proposed and worked out by Prof. B.M. Shtabsky methodical scheme of hygienic regulation of xenobiotics in food products (included in the textbooks on food hygiene in the section "Alimentary toxicology"), provides carrying out toxicological, hygienic and physiological studies, clinical and hygienic and epidemiological observations, and studying complex, combined action of harmful substances. From the point of view of the systematic approach to the regulation of xenobiotics Prof. B.M. Shtabsky has formulated the provision for the substantiation of a toxic individually permissible daily dose of xenobiotics as the basic standard of food hygiene. Under these provisions, such a standard of chemicals entry is only a set of products of daily nutrition and cannot be applied to the total entry of the substance with food, air and water because of different oral, inhalation, potential skin-resorptive toxicity, different quantitative ratio between the actual concentration in food, air and water, different nature of the combined effect of substances. Based on the developed methodological approaches, acceptable daily intakes
(ADI) $(\mathrm{mg} / \mathrm{kg}$ of body weight) for lead, cadmium, mercury, and arsenic with the daily diet are substantiated. For the first time he proposed to reduce the ADI of heavy metals in food products for the purpose of safety of food for people of all ages. The purpose of this work was to highlight a fragment of the results of the study concerning the experimental substantiation of standards of lead and cadmium in daily dietary rations. The basis for this was the record of the department's research work [3]. Head of research - Prof. B.M. Shtabsky, responsible executors - Prof. H.I. Stolmakova, V.I. Fedorenko, executors - R.I. Ladanivsky, V.M. Tomkiv, I.I. Siarchynsky, V.A. Samoliuk.

\section{MATERIALS AND METHODS OF RESEARCH}

Toxicological studies were conducted on sexually mature white rats in acute, subacute and chronic experiments. The effects of lead and cadmium nitrogens (further lead and cadmium) were studied. In acute experiments, the salt of metals was injected intragastrically with a probe with water, milk, and oil. $\mathrm{LD}_{50}$, the alimentary / water coefficient (the concept was introduced for the first time), the cumulative index, the average time of death of animals was determined. In subacute 30days' experiments the toxicity of metal ion forms entering with food and water in the dose range 1/10$1 / 10000 \mathrm{LD}_{50}$, as well as their bio-related forms in the doses $1 / 1000$ and $1 / 10000 \mathrm{LD}_{50}$ was evaluated. To obtain bio-related forms of metals, the aqueous solutions of metal salts were injected at a dose of $1 / 10 \mathrm{LD}_{50}$ daily to groups of animals during a month. The liver and kidneys were taken out (the animals were put asleep with ether), the tissues were homogenized, the concentration of lead and cadmium was determined, and the homogenate was stored in the freezer compartment. The obtained homogenates were added to the animals' food of experimental groups at a dose rate of $1 / 100$ and $1 / 1000 \mathrm{LD}_{50}$. Indicators of the action of metals were determined on the day 10,20 and 30 of the experiment. Additionally there was studied biorelated form of cadmium as "cadmium" lactic cheese, obtained by adding cadmium nitrate to fresh 
milk with milk kept in the thermostat at $37^{\circ} \mathrm{C}$ for two days. In the cheese, cadmium content was determined and a corresponding dose of metal was calculated. Cheese was added to animals' food, proportionally replacing the amount of casein in the diet. Chronic 9-month experiments were conducted to identify the impact of metals in ionic form entering the body with food and water at the stage of compensation and probable secondary decompensation stage, which may occur in the later stages of chronic intoxication in terms of the effect of small doses. In chronic experiments, $1 / 100,1 / 10000$ and $1 / 100000 \mathrm{LD}_{50}$ of lead were tested, with an additional $1 / 500000 \mathrm{LD}_{50}$ for cadmium. In subacute chronic experiments animals received lead and cadmium with drinking water and food and the amount of drinking water and food was monitored regularly. Animals received a standard semisynthetic isocaloric diet at a rate of $10 \mathrm{~g}$ per $150 \mathrm{~g}$ of body weight (the diet was developed at the Institute of Nutrition of the Academy of Medical Sciences of the former USSR in 1968). In this diet, lead and cadmium were absent in determining by the polarographic method. Indices of metal action were determined at the end of the day 1, 3, 5, 6, and 9 months of the experiment. Body weight of animals was controlled, in the blood - the number of red blood cells, leukocytes, hemoglobin, basophilic granularity of erythrocytes, concentration of sulfhydryl groups in blood serum and liver tissue by amperometric titration, blood serum activity was determined by the activity of ALT and AST (Reitman and Frenkel method, 1957), aldolase (V.I. Tovarnytsky and Ye.N. Voluyskaya method, 1963), cholinesterase (Hestrin method, 1949), alkaline phosphatase, concentration of cholesterol, urea, calcium, in bones including (biotests "Lachema"), in urine - concentration of dela-aminolevulinic acid - SALAL was determined (Semenova L.S. et al., 1982), coproporphyrin (Pavlovskaya N.A. et al., 1981), protein (Krynytska N.A., Boyarchenko K.L., 1983), in the adrenal glands - the level of ascorbic acid, behavioral reactions in the test of open field, physical performance of animals - by the time of keeping on the bar (Elizarova O.N., 1971). At the end of the $3^{\mathrm{d}}$ and $6^{\text {th }}$ months of the study histomorphology of the liver, kidney, and testis tissues was studied. The mutagenic properties of lead and cadmium were studied by cytogenetic method (metaphase analysis of bone marrow cells of white mice by Ford) in terms of action of $1 / 2 L_{50}$ of each metal and $1 / 8 \mathrm{LD}_{50}$ of lead and $1 / 16 \mathrm{LD}_{50}$ of cadmium in a single and repeated (7 days) action, as well in Ames test (1973). In some additional experiments (20 days), the effect of lead and cadmium in the dose range corresponding to their MAC in water of reservoirs and recommended by $\mathrm{FAO} / \mathrm{WHO}$ at the level of tolerant ones in entering of metals from three media (air, water, food) against lead and cadmium loading on day 6,13 and 20 of the experiments was studied. Dose-effect dependencies and a probable estimate of effective and maximal ineffective doses in the form of $\mathrm{DE}_{50}^{0}$ were analyzed [5]. Statistical analysis of the results of the study was carried out using the least squares method, with the determination of the probability of differences according to the Student's t-criterion.

\section{RESULTS AND DISCUSSION}

It was established that $\mathrm{LD}_{50}$ of lead nitrate (further lead) for white rats is $3599.5(3111.3 \ldots 4087.8) \mathrm{mg} / \mathrm{kg}$ (with water), $4400.7(3919.5 \ldots 4888.9) \mathrm{mg} / \mathrm{kg}$ (with milk), 4600.9 (4112.6...5089.2) $\mathrm{mg} / \mathrm{kg}$ (with oil), $\mathrm{LD}_{50}$ of cadmium nitrate (further cadmium) $200.0(153.1 \ldots 246.9) \mathrm{mg} / \mathrm{kg} \quad$ (with water), $216.6(175.9 \ldots 257.2) \mathrm{mg} / \mathrm{kg}$ (with milk), 250.0 (209.4...290.6) $\mathrm{mg} / \mathrm{kg}$ (with oil). Differences in $\mathrm{LD}_{50}$ values are improbable. The alimentary-water coefficient varies within 1.1-1.3. Lead cumulative indices $-0.15-0.29$, cadmium $-0.14-0.27$ indicate a strong degree of cumulation, which is confirmed by the average time of death of animals when determining $\mathrm{LD}_{50}-28.2$ and 27.5 hours, and the mean time at the moment of death, $1 / 2$ of $\mathrm{LD}_{50}$ of substance -3.47 and 2.81 days. In subsequent studies, doses of metal salts were evaluated on metal and $\mathrm{LD}_{50}$ of lead $2252.2(1946.7 \ldots 2557.7) \mathrm{mg} / \mathrm{kg}, \mathrm{LD}_{50}$ of cadmium $95.1(72.8 \ldots 117.4) \mathrm{mg} / \mathrm{kg}$ were taken into account.

In subacute experiments, the ionic form of lead in tested doses on entering with water and food has led to changes in all tested parameters that have been determined. Changes were dose-dependent. There was a decrease in the concentration of SH-groups in blood serum and liver tissue, calcium in blood serum and in bones, increased activity of the enzymes studied, suppressed unconditionally-reflex activity in experimental animals compared to control. The more pronounced changes occurred on the day 20 and 30 of the experiments. The dose-dependent changes in excretion of $\delta$-ALA and coproporphyrin with urine were the most indicative, in particular, on day 20 of the experiment when administered with water, and on day 30 when lead was consumed with food. Calculated by indices of excretion $\delta$-ALA with urine and $\mathrm{SH}$-groups in blood serum and liver tisssue $\mathrm{DE}_{50}^{0}=0.011 \quad(0.003 \ldots 0.044) \mathrm{mg} / \mathrm{kg}$ (with water) and $\mathrm{DE}_{50}^{0}=0.012(0.004 \ldots 0.038) \mathrm{mg} / \mathrm{kg}$ (with food) correspondingly. The average value of the alimentary-water coefficient of 1.09 indicates the absence of toxicity of the ionic form of lead entering with water and food. Similar values of the 
coefficient are found in other indicators. By excretion of coproporphyrin with urine, the maximal effects were detected at different levels of dose action at different observation periods: at the action of $1 / 10 \mathrm{LD}_{50}$ on day 10 of the experiment, $1 / 1000 \mathrm{LD}_{50}$ on day 20 (with water) and on day 30 (with food). The concentration of SH-groups in serum and liver tissue decreased in all terms of observation when lead entered with water and food. The most intense changes took place on day 30 days of the experiment. The average values of $\mathrm{DE}^{0}{ }_{50}$ by the level of SH-groups in the serum are $0.007 \mathrm{mg} / \mathrm{kg}$ (with water) and $0.006 \mathrm{mg} / \mathrm{kg}$ (with food). According to the results of the parallel study of ionic and bio-related forms of lead, the lowest values of the maximum inefficient dose of the metal based on the values of $\delta$-ALA concentration with urine on the basis of the analysis of dose dependences make up $\mathrm{DE}_{50}^{0}=0.039(0.015 \ldots 0.102) \mathrm{mg} / \mathrm{kg}$ for the ionic form and $\mathrm{DE}_{50}^{0}=0.038(0.018 \ldots 0.072) \mathrm{mg} / \mathrm{kg}$ for bio-related. According to the activity of cholinesterase in blood serum and liver tissue, the activities of AST in the blood serum, the two highest or two lowest doses of ionic or bio-related form of lead were found to be isoeffective. Probably this is due to the peculiarities of the kinetics of the effects of various forms of lead at different dose levels. However, in general, there are no probable differences between the effects of different forms of lead.

In chronic experiments, the action of lead in doses of $1 / 100-1 / 100000 \mathrm{LD}_{50}$ is realized wave-like with two practically identical maxima of effects after the 1 st and 9 th months of the experiment. It is noteworthy that some indicators only changed in the primary stage of decompensation (for example, the level of SH-groups in blood serum and liver tissue at the action of $1 / 100000 \mathrm{LD}_{50}$ or vitamin $\mathrm{C}$ in the adrenal glands), others only from the 6th month of the experiment (total cholesterol, body weight of animals), the STI changed in a directional manner, indicating the alternation of inhibitory and excitatory processes in the CNS. Probable differences in entring of lead with water or food were not detected. The most pronounced changes were observed with specific indicators of action of lead - coproporphyrin metabolism and decrease of SH-groups in blood serum and liver tissue, that is, by the same indicators as in subacute experiments. Analyzing the dose-effect dependences, the lowest value of $\mathrm{DE}_{50}^{0}$ was obtained by the level of $\delta$-ALA excretion with urine at the end of the 1 st month of the trial $\mathrm{DE}_{50}^{0}=0.0014(0.0005 \ldots 0.0038) \mathrm{mg} / \mathrm{kg}$ and the 9 th month $-\mathrm{DE}_{50}^{0}=0.0011(0.0004 \ldots 0.0028) \mathrm{mg} / \mathrm{kg}$ with lead in water and $\mathrm{DE}_{50}^{0}=$ $=0.0011(0.0005 \ldots 0.0027) \mathrm{mg} / \mathrm{kg}$
$\mathrm{DE}_{50}^{0}=0.0008(0.0006 \ldots 0.0012) \mathrm{mg} / \mathrm{kg}$, respectively, with food intake. Additional experiments conducted with loading by the lead confirmed the value of $\mathrm{DE}^{0}{ }_{50}=0.0011(0.0004 \ldots 0.0030) \mathrm{mg} / \mathrm{kg}$ by the level of $\delta$-ALA excretion with the urine of the experimental animals.

In the study of gonadotoxic activity of ionic form of lead with water and food at doses of 1/100 and $1 / 10000 \mathrm{LD}^{0}{ }_{50}$, at the end of 3 month of experiments, processes of degeneration in the epithelium (formation of "windows") were detected, between the tubules was acidophilic and vacuolized exudate, giant cells with acidophilic cytoplasm and dense cores. The index of spermatogenesis has not changed in comparison with control. At the end of the 6-month trial, the percentage of tubules with desquamated epithelium 2-4 times exceeded the control values. In most tubules, death of spermatogenic epithelium, connective tissue growth, edema, hypertrophy of interstitial glandulocytes, deposits of calcium salts have been observed. In the study of mutagenic properties under the conditions of one-time and repeated action of lead, it was found that the number of aberrations is $7.89 \pm 2.16$ and $6.2 \pm 1.94 \%$, respectively (control $0.60 \pm 0.22 \%$ ). In the Ames test it was established that in the absence of microsomal fraction S-9 of the liver of white rats lead did not reveal mutagenic properties, in the presence faction - lead appeared to be a weak mutagen to strain S.tyhymurium TA 100. To the strains TA 1538, TA 98 and TA 1535 differencies from control were not detected.

Earlier in the independent studies of Krasovsky G.M. et al. [4] and Zarubinskaya L.G. [2] MID were substantiated at $0.0015 \mathrm{mg} / \mathrm{kg}$ and $0.001 \mathrm{mg} / \mathrm{kg}$, respectively. These values are in the intervals of given $\mathrm{DE}_{50}^{0}$. Taking into account the absence of probable differences between the action of various forms of lead, the aggregate of $\mathrm{DE}_{50}^{0}$ levels, and comparing the data of scientific literature, the authors considered it advisable to accept the dose which does not exceed when it comes with water, i.e at the level of $0.0015 \mathrm{mg} / \mathrm{kg}$ of body weight as the most inefficient dose of lead that comes with food. In parallel, in the course of the department's research, background concentrations of lead were determined in food products, food rations of students, in the feed of laboratory animals and a background dose of lead was set at $0.0025 \mathrm{mg} / \mathrm{kg}$ of body weight. Based on the totality of the results obtained, taking into account the background dose of lead that comes with diet, DPD of lead is recommended at the level of $0.004 \mathrm{mg} / \mathrm{kg}$ per body weight (in terms of metal). We consider it expedient to add the following. Research report based on the results 
with regard to the lower limit of $\mathrm{DE}^{0}{ }_{50}$, expressed about the need to reduce the MID of lead with water to the level of $0.0005 \mathrm{mg} / \mathrm{kg}$, i.e. MIC and correspondingly MPC of lead in water would be reduced to $0.01 \mathrm{mg} / \mathrm{l}$ instead of the current MPC $0.03 \mathrm{mg} / \mathrm{l}$, which would require an official review in the relevant sections of the Problem Committees of the Academy of Medical Sciences. The value of MPC of lead in water at a level of $0.01 \mathrm{mg} / 1$ as a toxicological indicator of harmlessness of the chemical composition of drinking water later was specified in the State Sanitary Rules and the Norms "Drinking Water. Hygienic requirements for the quality of water for centralized household water supply", approved by Ministry of Health of Ukraine dated 23.12.1996, N 383) and still are in force (DSanRandN 2.2.4 - 171-10, Ministry of Health of Ukraine, May 12, 2010, N 400). Let us recall also that a joint committee of experts $\mathrm{FAO} / \mathrm{WHO}$ on food additives in 1972 recommended tolerable dose of lead for adults at a level of $7 \mathrm{mcg} / \mathrm{kg}$ of body weight per day, which extended to the total entry of lead with food, water and air. In 1986 experts of FAO/WHO reduced this dose twofold $(3.57 \mathrm{mcg} / \mathrm{kg}$ of body weight per day) for children, and since 1993 this dose concerned adults as the total on in entering from the same three environments. Along with this, already in 1990, B.M. Shtabsky et al., presented an experimentally substantiated single DPD of lead for adults and children at a level of $4 \mathrm{mcg} / \mathrm{kg}$ body weight, which included the maximum dose intake and the background dose of lead in the typical diet According to this DPD, the daily allowance of lead with is $240 \mathrm{mcg}$ for adults, $60 \mathrm{mcg}$ - for children up to 3 years, $80 \mathrm{mcg}$ - for those of 4-7 years $[6,7]$.

In subacute experiments, all test doses and forms of cadmium were brought about to the changes in blood serum and animals' tissues as compared to the control group. Hemoglobin level, red blood cells count, the activity of alkaline phosphatase, ALT and AST in blood serum, level of SH-groups in serum and liver tissue, calcium in serum and bones, STI decreased, concentration of protein and $\delta$-ALA in urine, blood urea increased. In separate observation periods, dose dependence of changes was noted, in other cases - the doses were isoeffective and shifts were statistically significant. In general, with a decrease in the dose of ionic and bio-related forms of cadmium, the number of tests by which significant changes were observed primarily they were of nonspecific action, and the degree of shift in time of the maxima is practically the same irrespective of the action of the form of cadmium. The most indicative tests were the level of SH-groups in blood serum and liver tissue with a maximum shift on day
30 day of experiments, protein in urine and serum urea (in the latter case, concomitant doses were often isoeffective). We give only the lowest values of the maximum ineffective doses obtained on the basis of dose dependence analysis. This is primarily due to the concentration of SH-groups on day 30 of the experiments and proteinuria index on day 20 . Estimation of $\mathrm{DE}_{50}^{0}$ by the indicator of $\mathrm{SH}$-groups in blood serum on entering cadmium with water and food resulted in the values of $\mathrm{DE}_{50}^{0}=0.000081(0.00000015 \ldots 0.000437) \mathrm{mg} / \mathrm{kg}$ and $\mathrm{DE}_{50}^{0}=0.00023(0.00007 \ldots 0.00076) \mathrm{mg} / \mathrm{kg}$, respectively, by the SH-group in the liver tissue $\mathrm{DE}^{0}{ }_{50}=0.00051(0.00019 \ldots 0.00137) \mathrm{mg} / \mathrm{kg}$ and $\mathrm{DE}_{50}^{0}=0.00026(0.00007 \ldots 0.00096) \mathrm{mg} / \mathrm{kg}$, respectively, by the concentration of protein in urine $\mathrm{DE}_{50}^{0}=0.00010(0.0001 \ldots 0.00083) \mathrm{mg} / \mathrm{kg}$ (with water) and $\mathrm{DE}_{50}^{0}=0.00038(0.00008 \ldots 0.00189) \mathrm{mg} / \mathrm{kg}$ (with food ) On day 20 of experiments under the action of the biosphere form of cadmium (adding of tissue homogenates) for $\mathrm{SH}$-groups in the liver tissue $\mathrm{DE}_{50}^{0}=0.00095(0.00019 \ldots 0.00476) \mathrm{mg} / \mathrm{kg}$, which practically coincides with the minimum values under the action of ion forms of cadmium for the entire period of observation. The results of the test of "cadmium" cheese and "cadmium" homogenate of the liver and kidney tissues practically also coincide. Formally, guided by the statistically significant differences in the degree of shifts, it can be noted that these bio-related forms in different terms of observation caused changes from not the same indicators. And it is not strange. According to the laws of mathematical statistics, the more tests are being investigated and taken into account, the less likely it is that even in parallel groups of control animals all of them will appear within the limits of statistical "norm". Consequently, in the chosen conditions of experiments, toxicometric significant differences in the action of ion forms of cadmium coming with water and food, as well as bio-related forms were not detected.

In terms of chronic investigations, the main results are as follows. With food the dose of $1 / 100 \mathrm{LD}_{50}$ proved to be effective in all of the determined parameters, with a dose reduction to $1 / 10000 \mathrm{LD}_{50}$, practically all the indices were statistically significantly changed compared to control, with the exception of the body weight of animals, the number of red blood cells and physical capacity. At the level of $1 / 100000 \mathrm{LD}_{50}$, the probable changes were detected by the level of SH-groups in serum, urine protein at the end of 1,6 , and 9 months of the experiment, as well as by SH-groups in the liver tissue at the end of 9th month. The dose of $1 / 500000 \mathrm{LD}_{50}$ was ineffective in all indications, 
except for the level of SH-groups in serum at the end of a chronic trial. If we do not overestimate the role of the statistically significant difference between the trial and control in this single case (the degree of changes was $20 \%$ and coincided with the action of $1 / 100000 \mathrm{LD}_{50}$ ) then the dose of $1 / 100000 \mathrm{LD}_{50}$ which corresponds to $0.00095 \mathrm{mg} / \mathrm{kg}$ can be considered as the minimum effective (threshold), and that of $0,00019 \mathrm{mg} / \mathrm{kg}\left(1 / 500000 \mathrm{LD}_{50}\right)$ - as the most ineffective. The dynamics of changes by this indicator, as well as by the concentration of urea and the activity of alkaline phosphatase in serum testify to the phase character of the development of the toxic process in time with the stage of primary adaptation at the end of $3 \mathrm{~d}$ month of the experiment. Analysis of the relationship of effects with doses by the level of SH-groups in serum and protein in the urine at the end of the 6th month of the experiment led to $\mathrm{DE}_{50}^{0}=0.00022(0.00005 \ldots 0.00100) \mathrm{mg} / \mathrm{kg}$ and $\mathrm{DE}_{50}^{0}=0.00047(0.00027 \ldots 0.00081) \mathrm{mg} / \mathrm{kg}$, respectively. At the end of the 9 th month of the experiment by the concentration of protein in the urine $\quad \mathrm{DE}_{50}^{0}=0.00015(0.00005 \ldots 0.00046) \mathrm{mg} / \mathrm{kg}$. Comparison of the effects of the same doses of ionic form of lead on entering with water and food in comparable experimental conditions leads to statistically unlreliable effects. In additional studies with cadmium loading (a dose of $0.00005 \mathrm{mg} / \mathrm{kg}$ was tested), changes were detected on day 6 and 12 of experiments on the level of SH groups in serum, $\delta$-ALA and protein in urine $(0.01 \mathrm{mg} / \mathrm{kg}$ and $0.001 \mathrm{mg} / \mathrm{kg}$ body weight), $0.00005 \mathrm{mg} / \mathrm{kg}$ dose is ineffective. Formal analysis of the relation of the effects with doses on day 6 and 12 of the experiments by the effect on the level of SHgroups in serum revealed the value $\mathrm{DE}_{50}^{0}=0.00027(0.00012 \ldots 0.00058) \mathrm{mg} / \mathrm{kg} \quad$ and $\mathrm{DE}_{50}^{0}=0.00011(0.00005 \ldots 0.00027) \mathrm{mg} / \mathrm{kg}$, due to the effect on the concentration of $\delta$-ALA in urine $\mathrm{DE}_{50}^{0}=0.00017(0.00008 \ldots 0.00036) \mathrm{mg} / \mathrm{kg}$. The obtained values are of the same order as the results of chronic experiments. In the study of gonadotoxic activity of cadmium, it was found that at the end of the $3 \mathrm{~d}$ month of the experiment, ionic forms of cadmium with water and food in doses of 1/100 and $1 / 10000 \mathrm{LD}^{0}{ }_{50}$ caused the death of the spermatogenic epithelium, at the end of the 9th month - the percentage of tubules with peeled epithelium was 3-9 times higher than in control. Between the tubules hypertrophied interstitial glandulocytes, vacuolized homogeneous mass, were accumulated in the tubules - giant cells with acidophilic cytoplasm and dense nuclei. In the study of mutagenic properties under conditions of one-time and repeated exposure to cadmium, it was found that the number of aberrations was $4.29 \pm 1.64$ and $4.7 \pm 1.88 \%$ respectively (control $0.60 \pm 0.22 \%$ ). The Aames test found that in the absence of the microsomal fraction S-9 of the liver of white rats, cadmium did not exhibit mutagenic properties; in the presence of the fraction, cadmium was found to be an average mutagen to TA 1535 strain. To strains TA 1538, TA 98 and TA 100 differences from control were not detected.

In general, based on the results obtained, it is possible to take as the most ineffective dose of cadmium for the regulation of DPD with food products $-0.0001 \mathrm{mg} / \mathrm{kg}$ and $0.00005 \mathrm{mg} / \mathrm{kg}$ body weight. From the standpoint that the official normative status of the most ineffective dose of cadmium in regulating the MPC of cadmium in water is $0.00005 \mathrm{mg} / \mathrm{kg}$ (MPC $-0.001 \mathrm{mg} / \mathrm{l}$ ), the authors of the research considered it appropriate to recommend a maximum ineffective dose of cadmium at the level of $0.00005 \mathrm{mg} / \mathrm{kg}$. Given the detected cadmium natural food background (background cadmium dose with food at $0.0005 \mathrm{mg} / \mathrm{kg}$ body weight), the DPD value is recommended at the level of $0.00055 \mathrm{mg} / \mathrm{kg}$ body weight. According to this DPD, permissible daily intake of cadmium with food is for adults (body weight $60 \mathrm{~kg}$ ) 33 micrograms, for children under 3 years of age (body weight $15 \mathrm{~kg}$ ) - 8 micrograms, 4-7 years (body weight $20 \mathrm{~kg}$ ) - 11 micrograms. We would add that the recommended DPD is practically identical to the reference dose (US EPA, 1991), set at $0.5 \mathrm{mcg} / \mathrm{kg}$ body weight [1], as well as the value of a temporary tolerable month's dose for cadmium at $25 \mathrm{mcg} / \mathrm{kg}$ body weight (daily dose at the level of $0.83 \mathrm{mcg} / \mathrm{kg}$ body weight) proposed by the FAO / WHO and the Food Additives Expert Committee (JECFA) in 2010 [8]. With the development of molecular biology, biochemistry, etc. and given epidemiological observations, DPD of lead and cadmium may be reduced over time.

\section{CONCLUSIONS}

1. Lead nitrate belongs to low-toxic, cadmium nitrate - to medium-toxic compounds with a strong degree of cumulation. Toxicity and degree of cumulation of compounds does not depend on whether they come with water, milk, and oil.

2. Under the selected conditions of sub-chronic and chronic experiments, it was established that when toxic ions of lead and cadmium enter animals' body with water and food, as well as bio-related forms (liver and kidney homogenates, lactic acid cheese) toxicometric significant differences are absent.

3. Under conditions of subacute and chronic experiments, the most indicative tests were: 
concentration of $\delta$-ALA and coproporphyrin in urine in the action of lead and concentration of SH-groups in blood serum and liver tissue and protein in urine in the action of cadmium.

4. Lead and cadmium have expressed gonadotoxic activity, cause genetic effects that are manifested by the cytogenetic method and in the Ames test in the presence of the microsomal fraction of the liver.

5. Based on the analysis of the dose-effect dependences in sub-chronic and chronic experiments, taking into account the results obtained by the method of loading by the same name metals, there were substantiated maximum ineffective overbackground doses in the form of DE050 for lead at the level of $0.0015 \mathrm{mg} / \mathrm{kg}$, for cadmium $0.00005 \mathrm{mg} / \mathrm{kg}$ irrespective of ionic or bio-related forms.

6. Permissible daily doses of lead and cadmium with food at the level of $0.004 \mathrm{mg} / \mathrm{kg}$ and $0.00055 \mathrm{mg} / \mathrm{kg}$ body weight respectively are recommended, taking into account the natural metallic background in foods products.

\section{REFERENCES}

1. Gzhegotskyi MR, Fedorenko VI, Shtabskyi BM. [Sketches of prophylactic medicine]. In: Shtabskoho BM, editor. Lviv, Medytsyna i pravo. 2008;400. Ukrainian.

2. Zarubinskaya LG. [Lead in the environment]. In: Sidorenko GI, Zolotova PA, editors. Moskva. 1978;50-52. Russian.

3. [To study the contents of cadmium and lead in the food of Western region of Ukraine, to develop methodical approaches to the hygienic reglamentation of Heavy metals in the food and to establish the norms for Cadmium and Lead in the daily diet (the final report)]. In: Shtabskiy BM, editor. Lvov. 1989;107. Russian.

4. Krasovskiy GN, Charyiev OG, Varshavskaya SP. [Lead in the environment]. In: Sidorenko GI, Zolotova PA, editors. Moskva. 1978;48-50. Russian.

5. Shtabskiy BM, Krasovskiy GN, Kudrina VN, Zholdakova ZI. [On the probabilistic estimation of effective and sub-background doses in the toxicological experiment]. Gigiena i sanitariya. 1984;6:13-16. Russian.

6. Shtabskyi BM, Fedorenko VI. [Lead exchange and aims of prophylactic and clinical medicine]. Eksperymentalna ta klinichna fiziologiia $i$ bioximiia. 2000;2:109-12. Ukrainian.

7. Shtabskyi BM, Fedorenko VY, Samoliuk VA, Siarchynskyi VM. [Experimental justification of maximal daily doses of lead and cadmium in the diet]. Environmental Protection and Public Health. Conference. Tartu. 1990;127-9. Russian.

8. Preventing disease through healthy enwerionments. Exposure to cadmium: a major public health concern. [Internet]. WHO 20 Avenue Appia, 1211 Geneva 27, Switzerland Available from: https://www.who.int/ipcs/features/cadmium.pdf

\section{СПИСОК ЛІТЕРАТУРИ}

1. Гжегоцький М. Р., В. І. Федоренко, . М. Штабський. Нариси профілактичної медицини / за ред. Б. М. Штабського. Львів, 2008. 400 с.

2. Зарубинская Л. Г. Свинец в окружающей среде / под ред. Г. И. Сидоренко, П. А. Золотова. Москва, 1978. С. 50-52.

3. Изучить содержание кадмия и свинца в пищевых продуктах западного региона УССР, разработать методических подходы к гигиеническому регламентированию тяжелых металлов в продуктах питания и установить нормативы кадмия и свинца в суточных рационах питания (заключительный отчет) / под ред. Б. М. Штабского. Львов, 1989. 107 с.
4. Красовский Г. Н., Чарыев О. Г., Варшавская С. П. Свинец в окружающей среде / под ред. Г. И. Сидоренко, П. А. Золотова. Москва, 1978. С. 48-50.

5. Штабский Б. М., Красовский Г. Н., Кудрина В. Н., Жолдакова 3. И. О вероятностной оценке эффективных и подпороговых доз в токсикологическом эксперименте. Гигиена и санитария. 1984. № 6. С. 13-16.

6. Штабський Б. М., Федоренко В. І Обмін свинцю і завдання профілактичної та клінічної медицини. Експериментальна та клінічна фізіологія $i$ біохімія. 2000. № 2. C. 109-112. 
7. Экспериментальное обоснование допустимых суточных доз свинца и кадмия при поступлении в организм с пищей / Б.М. Штабский и др. Охрана окружающей среды и здоровье населения: материалы конф. Тарту, 1990. С. 127-129.
8. Preventing disease through healthy environments. Exposure to Cadmium: a major public health concern. WHO 20 Avenue Appia, 1211 Geneva 27, Switzerland URL: https://www.who.int/ipcs/features/cadmium.pdf

The article was received 2019.01.29

Shupyk National Medical Academy of Postgraduate Education ${ }^{1}$

Dorohozhytska str. 9, Kyiv, 04112, Ukraine

e-mail: khomen2010@ukr.net

Tokmak Interdistrict Department of the State Institution «Zaporizhzhia Regional Laboratory Center of the Ministry of Health of Ukraine» $^{2}$

Hohol str., 44, Tokmak, Zaporizhzhia region, 71708, Ukraine

e-mail: n.zakladnaya@gmail.com

НМАПО ім. П.Л. Шупика ${ }^{l}$

вул. Дорогожицька, 9, Київ, 04112, Україна

Токмаџький міжрайонний відділ ДУ «Запорізький обласний лабораторний центр МОЗ Украӥни»

вул. Гоголя, 44, Токмак, Запорізька область, Украӥна

\section{Цитування: Медичні перспективи. 2019. Т. 24, № 1. С. 80-86}

Cited: Medicni perspektivi. 2019;24(1):80-86

Key words: nuclear power plants, observation area, environment, levels of pollution, radionuclides, radiation-hygienic monitoring

Ключові слова: атомні електростанщії, зона спостереження, навколишнє середовище, рівні забруднення, радіонукліди, радіаційно-гігієнічний моніторинг

Ключевые слова: атомные электростанщии, зона наблюдения, окружающая среда, уровни загрязнения, радионуклиды, радиационно-гигиенический мониторинг

Abstract. Improving the system of radiation and hygienic monitoring of environmental objects in the areas of observation of Ukrainian nuclear power plants as a fundamental of radiation safety. Khomenko I.M., Zakladna N.V. The relevance of the work is determined by the absence of documents on the problems of observation areas of nuclear power plants, including the organization and monitoring of environmental objects in Ukraine. The 